\title{
Analyze the Local Wisdom Contained in Lubuk Larangan Tradition in Tanjung Belit Village, Kampar Kiri Hulu District
}

\author{
Swis Tantoro \\ Department of Sociology, Fisip Universitas Riau, Indonesia \\ Received December 21, 2019; Revised March 10, 2020; Accepted May 13, 2020
}

Copyright $\bigcirc 2020$ by authors, all rights reserved. Authors agree that this article remains permanently open access under the terms of the Creative Commons Attribution License 4.0 International License

\begin{abstract}
Purpose: (1) To identify the social, economic, and cultural characteristics of Tj. Belit Village, Kampar Kiri Hulu District; (2) To know the management of Lubuk Larangan in Tj. Belit Village, Kampar Kiri Hulu District; and (3) To analyze the local wisdom contained in Lubuk Larangan tradition in Tj. Belit Village, Kampar Kiri Hulu District. Design/Method: The research approach used in this study is the qualitative approach. The research location is in Tanjung Belit Village, Kampar Kiri Hulu District, Kampar Regency, Indonesia. The informants were chosen based on a specific purpose to obtain the broadest picture about the local wisdom of the community in maintaining Lubuk Larangan tradition Tanjung Belit Village, Kampar Kiri Hulu District, Kampar Regency. Findings: (1) The management of Lubuk Larangan is intended to protect the prohibited area. The management procedures include the supervision, regulation, sanction, harvesting, and sales. (2) The forms of local wisdom contained in the management of Lubuk Larangan tradition are 1). Fish should not be taken prematurely, 2). Catch the fish with Ethno-technology, 3). Maintain the vegetation of river banks, 4). Only big fish that can be caught. (3) The efforts to maintain local wisdom (local genius) of Lubuk Larangan are to maintain the river unpolluted by keeping the forest ecosystem and preventing forest encroachment as well as maintaining the river biodiversity population by non-poisoning the fish, not harvest the small fish, and cooperate with various parties such as non-governmental organizations like WWF and local government. Originality: This research is one of the few studies that examine the management of Lubuk Larangan, especially in the village of $\mathrm{Tj}$. Belit, Kampar Kiri Hulu District. This research is expected to provide a description related to the substance of local wisdom contained in the management of Lubuk Larangan and to provide recommendations in the form of strategy in the preservation of local wisdom values to maintain Lubuk Larangan tradition in Tj. Belit Village,
\end{abstract}

Kampar Kiri Hulu District.

Keywords Social Characteristic, Economic Characteristic, Cultural Characteristic, Management, Local Wisdom

\section{Research Background}

Indonesian society consists of various tribes and many cultures. The culture of the nation is a culture that arises from efforts of Indonesian people as a whole. A culture is a medium to solve problems by people. According to E. B Tylor, culture is a complex thing that includes knowledge of belief, art, morals, law, customs, and other abilities and habits gained by humans as members of society.

Culture has a broad and common meaning. In the concept of culture, there is a tradition which has a more special meaning. Tradition is also defined as a habit passed down from generation to generation. Shils in [23] defined tradition as anything that is transmitted or passed from the past to the present. Tradition is a kind of act done repeatedly in the same form. In Indonesian Dictionary, tradition is the hereditary customs (of ancestors) that are still practiced today by the society. Thus, tradition is a habit perpetuated by society and will be passed down from generation to generation.

The function of a cultural system is to organize and consolidate human actions and behavior. The learning process of a cultural system is done through culture or institutionalization. In the institutionalization process, an individual learns and adapts his/her mind and attitude to the customs, norms, and rules that live in the culture. Once the feelings and cultural values that motivate the imitating act are internalized in his/her personality, the action becomes a steady pattern and the norm will govern the action [20]. One form of container in the cultural system is Local 


\section{Wisdom.}

Local wisdom is a creative response to the geographic-political, historical, and situational situations that are local in nature. This contains the attitudes, views, and abilities of a society in managing its spiritual and physical environment. Those are the efforts to give a resilience and growing power in the area where the community is located.

Kampar Regency is an area that has the potential of culture and nature tourism which can be developed. One of which is the potential of maritime tourism along the Subayang river. There is a tradition that is still well preserved by the local community that is Lubuk Larangan tradition. Lubuk Larangan is one of the local wisdoms that is jointly managed and usually has a legal entity in which the rules are mutually agreed upon by the leaders in the Kenegerian which include: Ninik Mamak, Village Council, and Youth Organization.

Etymologically, Lubuk Larangan consisting of the word "lubuk" and the word "larang". In the Indonesian Dictionary, the word "lubuk" means "deep place in the river, lake, or sea", while the word "larang" means "a command which forbids an act". If "larang" is added with a suffix -an, it will be "larangan". Lubuk Larangan means a hole, a part of the river that splits and is a place for fish to lay eggs. It is prohibited and restricted to catch the fish for a certain period of time on the basis of mutual agreement with the community. Simply put, people will quickly interpret it as a certain protected area in a river for a certain period.

The community which lives on the edge of the river carries out the tradition through Panen Ikan (harvesting) in a place called Lubuk Larangan where the area has been agreed to be prohibited under customary laws. Essentially, it is prohibited to catch fish in any system. Therefore, what is meant by Lubuk Larangan is a restricted river area. Lubuk is part of a particular location which, in this case, the area in a river that has a maximum depth, for example, 3 to 4 meters. This place is deliberately chosen and will certainly be favored by large fish. This new territory can be harvested based on custom deliberations. Lubuk Larangan was created since 1978 and deliberately developed at the cultural level because, basically, it is very beneficial to the community located alongside the Subayang river in Kampar Kiri Hulu District, Kampar Regency, Riau.

Based on the research background and the formulation of the problem above, the objectives of this research are: (1) To identify the social, economic, and cultural characteristics of $\mathrm{Tj}$. Belit Village, Kampar Kiri Hulu District; (2) To know the management of Lubuk Larangan in Tj. Belit Village, Kampar Kiri Hulu District; and (3) To analyze the local wisdom contained in Lubuk Larangan tradition in Tj. Belit Village, Kampar Kiri Hulu District.

This research is one of the few studies that examine the management of Lubuk Larangan, especially in the village of $\mathrm{Tj}$. Belit, Kampar Kiri Hulu District. This research is expected to provide a description related to the substance of local wisdom contained in the management of Lubuk
Larangan and to provide recommendations in the form of strategy in the preservation of local wisdom values to maintain Lubuk Larangan tradition in Tj. Belit Village, Kampar Kiri Hulu District.

Several previous studies were used as references in this research separately, such as The Tradition of Management by Garah, W., I., et al. in [7], Kletz, P., et al. in [11], Naughton, M., et al. in [16], Peters, B.G. in [18], Vrontis, D., et al. in [24]; Local wisdom by Adams, A. in [2], J. Adler, N. In [9], Kusumasari, B. and Alam, Q. in [12], Radix A.P. Jati, I. in [19], Sibarani, R. (2012); Local indigenous by Fuller, C. And DelliSanti, D. (2017), Gowda, K., et al. (2008), Sibarani, R. in [22], Lavan, I. in [13], Wilkus, E.L., et al. in [25], A. Schneider, R. in [16]. The originality for this paper shows the comprehensively The Tradition of Management, Local wisdom and Local indigenous.

\section{Literature Review}

Local wisdom in the anthropological discipline also known as a local genius. Local genius is the first term introduced by Quaritch Wales [4]. The anthropologists have long discussed the sense of this local genius term. Among others, Haryati Soebadio said that local genius is a cultural identity; an identity or personality of the nation's culture that causes the nation able to absorb and manage foreign cultures according to their own characters. On the other hand, Ayatrohaedi in [4], explained that local culture has a potential of local genius because it has been proven to survive until now. The characteristics of local knowledge are: (1) The ability to resist foreign cultures, (2) The ability to accommodate the elements of foreign cultures, (3) The ability to integrate the elements of foreign culture into native culture, (4) The ability to control, and (5) The ability to give direction to the development of culture.

Sibarani in [22] also believed that local wisdom is the original wisdom or knowledge of a society derived from the noble value of cultural traditions to regulate the life of society. Local wisdom also can be defined as the value of local culture which can be used to regulate the social order in a wise or prudent way.

By that, it can be interpreted that local wisdom is formed as the culture of local communities linked with the geographical condition in a broad sense. Local wisdom is a cultural product of the past that should be constantly used as the grip of life. Although it is a local value, the value contained is considered to be very universal.

Local wisdom is an explicit knowledge which arises from periods of time and evolves together with society and the environment in the local system that has been experienced together. The long process of evolution is deeply embedded in the society in which it can be served as a local source from the collective knowledge of the community to live dynamically and peaceful together. This understanding sees local wisdom not merely as a reference of one's behavior, but further, that is capable to dynamize 
the life of a civilized society.

\section{Lubuk Larangan Boundaries}

Bottom border restrictions with no depth restrictions are marked by differences in river flow velocity. A relatively quiet area is designated as an area of prohibition, while a part where the river flows faster is not defined as an area of prohibition. Areas where fishing is prohibited at certain times of the year are those within where the flow is relatively quiet and shaded by dense vegetation. This location is a very desirable place for different species of fish to live. The natural wisdom of elders has led them to choose certain areas (usually about $2-3 \mathrm{~km}$ in area) to become lubuk larangan. A bottom boundary restriction usually uses natural signs or specific trees. After the location restrictions specify the depths of prohibition, the decision is announced to all children across the country and to people who live in that location in the Upper State or Aur Sanggan Yellow Stone to downstream of the village of Kuntu. From that time, all children and locals abide by the rules that apply to a lubuk larangan. Utilisation in this way does not damage the fishing, spawning or fish nursery grounds. Local knowledge in determining the boundary region show that local people know fish generally like the relatively calm waters, as fish food sources are much more likely to be found in these calmer river waters.

\section{Lubuk Larangan of Customary Regulation}

In managing the bed of the river, Lubuk Larangan has been carried out by a traditional institution, the Ninik Mamak in Domo Village. The traditional institution is led by two men, Datuk Sutan Bandaro and the prince. These two progenitors are assisted by five princes of the second offspring derived from the progenitor. In 2007 the rules of customary lubuk larangan were confirmed in a letter by the Ninik Mamak. The customary decision was issued with consideration for preserving the fish resources in the River Subayang at Domo Village. Customary rules decided by Mamak Ninik traditional institutions are: 1. Any players catching fish in the depths of the region ban will be subject to sanctions of rupiah (Rp) 500,000 per fish. 2. Buyers or fences will have imposed sanctions of $\mathrm{Rp} 500,000$ per person. 3. If the receiver catches the perpetrator, it will be processed by Dubalang Ninik Mamak to be resolved according to customary nephew mamak concerned. 4 . If points 1 and 2 are performed by Ninik Mamak, the village officials and members of the Village Representative Body will impose sanctions of $R p$ 1,000,000. Impact of Lubuk Larangan, the socioeconomic impact of applying the lubuk laranganlubuk larangan depths are as follows. It can provide a source of protein for Domo villagers through the availability of local fish harvested once a year. Clean water sources are available for daily necessities to the surrounding community. biological resources of the local fishery are available to be used for eco-tourism; The community can enhance the feeling of love and concern for the biodiversity and conservation of fisheries resources. Harmony and a sense of solidarity are manifested in the social environment and a commitment to the local tradition of the show, Mancuak (the harvest once a year to fund social activities). There is the realization of the institutions of society through customary activities to conserve the biodiversity of fisheries resources [27].

Substantially, local wisdom is the prevailing values in a society. Values are believed to be true and become a reference in the daily behavior of local people. Therefore, it is reasonable to say that local knowledge is crucial entities and human dignity in the community. It means that local wisdom, which contains the elements of creativity and local knowledge of the elites and the people, determines the development of society civilization.

In our community, local wisdom can be found in traditions, songs, proverbs, sasanti, adverbs, slogans, and ancient books embedded in everyday behavior. Local wisdom is usually reflected in the life habits of a community. The sustainability of local wisdom will be reflected in the values within a particular group of a society. They become the guidance of certain groups of people which will usually be an integral part of life. This can be observed through their daily attitudes and behaviors.

The definition of local (traditional) wisdom according to Keraf in [10] are all forms of knowledge, beliefs, understandings, insights, and customs or ethics that guide human behavior in life in the ecological community.

The above definition provides a perspective that mankind is an integral part of the universe which has full responsibility, respect, and care for the sustainability of life in the universe as well as changing the anthropocentrism perspective into biocentrism and eco-centrism perspective. The values of local wisdom contained in the society's social system can be lived, practiced, taught, and inherited from one generation to another that simultaneously form and guide patterns of everyday behavior both to humans and nature. Generally, indigenous people have a system of local knowledge and management that is inherited and continuously developed from generation to generation. In this case, indigenous people are a society that traditionally depends and has a strong socio-cultural and religious connection with its local environment.

According to Ataupah in [3], local wisdom is historical but positive. The values are built by the ancestors and then passed to the next generation orally. Then, the heirs did not receive the values passively but they add or subtract and process it so that it is called as local wisdom. Local wisdom is applicable, situational, and indivisible from the environmental or ecological systems that must be faced by those who understand and exercise that wisdom.

The framework of thought in this study is the scope of assumptions and concepts which will be used in an effort to identify local wisdom that is still going on in the management of Lubuk Larangan tradition that is described as follows: 


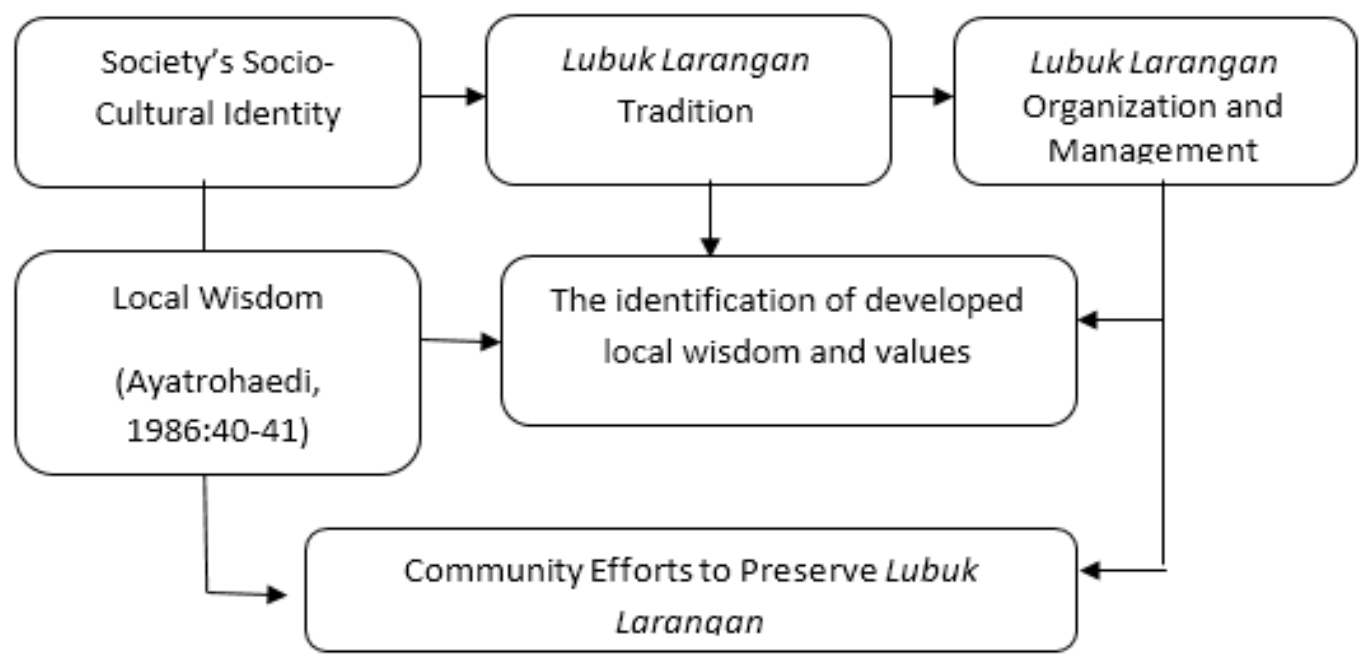

Figure 1. The Framework of Thought

The results of studies relevant to this research are as follows: First, Parwati et al [17], with their title: "The Value of Environmental Conservation in Lubuk Larangan Ngalau Agung Local Wisdom in Kampuang Surau, Dharmasraya Regency, West Sumatra Province". Lubuk Larangan Ngalau Agung is a certain area on a river where the community gives a limit to the place, in which it is prohibited to disturb and to catch fish in Kampuang Surau, Dharmasraya Regency, West Sumatra Province. Lubuk Larangan Ngalau Agung's area is $1 \mathrm{~km}$ in length, $15 \mathrm{~m}$ in width, $1.25 \mathrm{~m}$ in depth of Batang Pangian River; and it is 1 $\mathrm{km}$ in length and $5 \mathrm{~m}$ in width on the land. This study identifies the values of the environmental preservation in the Lubuk Larangan Ngalau Agung local wisdom. The results of the study indicate that the community's compliance with the area's given boundaries and prohibition has a positive impact on the environmental conservation. The value of environmental preservation in the implementation of Lubuk Larangan Ngalau Agung local wisdom is the prohibition to harm, to take, and to disturb the fish, as well as to say bad words (be haughty) or to behave badly around the area.

Second, Yuliati and Priyatna [27], with their title "Lubuk Larangan: The Dynamics of Communities' Local Knowledge in the Management of Fisheries Resources in the River Waters of Lima Puluh Kota Regency". This study illustrates how the local communities have knowledge in managing fisheries resources in the river waters. This knowledge embodies the value of local wisdom, life philosophy, religion and local legal norms applied in the use of resources. The results of the study show that Lubuk Larangan is not only a practice of fish resources utilization, but there are also rules and mechanisms for distributing the customary rights and organization. In accordance with its dynamic nature, the knowledge of managing Lubuk Larangan has also changed. Islamic values and government politics are the drivers of change in Lubuk Larangan management.
Third, Lubis [14], in a Journal of Indonesian Anthropology Vol. 29 University of North Sumatra, with the title: "(Re-) Growing the Local Wisdom in The Natural Resource Management in South Tapanuli". This paper began on the assumption that the local wisdom (once) existing in the natural resource management (especially forests) can be revitalized to build participation if all relevant stakeholders are capable of growing and building the social capital between them, based on the consensus and new (renewed) commitment collectively formulated. The research problems are addressing what the original knowledge or wisdom of the South Tapanuli Regency's community in managing their natural resources is, and how to best utilize these cultural treasures to encourage community participation in saving the forests in South Tapanuli. The results of this study, that are re-growing the local wisdom of the past and the forms of environmental wisdom in natural resource management known by the Angkola/ Mandailing community, are usually packed in terms of forbiddance (religio-magical pattern) and Rarangan/ Larangan (prohibition - customary law rules). Although it has a rather different ideological foundation, both of them have a positive effect on the conservation of natural resources. On the other hand, the regulation of customary law regarding the division and control of territory and the use of existing resources are also effective in anticipating cross-border exploitation. However, the ideological foundation and sociopolitical structures framing the relationship between humans (communities) and forests (natural resources) have currently changed; this directly or indirectly brings the effect of weakening the local communities' ability in developing a sense of wisdom.

Fourth, Firdaus and Huda [5], with their title "Fish Resource Management in Rivers (Case Study: In Pesisir Selatan District, West Sumatra Province)". The results of this study indicate that the management of fish resources in the rivers of Pesisir Selatan District is managed by the 
community in the form of indigenous conservation areas or known as Lubuk Larangan. Meanwhile, the establishment of the Lubuk Larangan must have the regulations from the Nagari (an area or group of villages led by a headman) and have groups that manage them. Lubuk Larangan in Pesisir Selatan District has been established through the Decree of the Regent of Pesisir Selatan No. 523 of 2007, concerning the Determination of Freshwater Aquatic Indigenous Conservation Areas. The existence of Lubuk Larangan has provided benefits, such as preserving fish resources and improving the economy of the community around the Lubuk Larangan, by setting up stalls that sell drinks and snacks for visitors.

\section{Research Method}

The research approach used in this study is the qualitative approach. Bogdan and Taylor stated that qualitative methodology is a research procedure that produces descriptive data in the form of written or oral words from observable persons and behaviors. This approach is directed to the individual's background in a holistic way. Therefore, the researchers did not isolate the individuals or organizations into variables or hypotheses but to view them as part of a wholeness.

The research location is in Tanjung Belit Village, Kampar Kiri Hulu District, Kampar Regency. The informants were chosen based on a specific purpose to obtain the broadest picture about the local wisdom of the community in maintaining Lubuk Larangan tradition Tanjung Belit Village, Kampar Kiri Hulu District, Kampar Regency. To determine the subjects in this study, the researchers used a purposive method that is a method of selecting the informant carefully so that it is relevant to the research structure. The informants were picked by selecting the people based on the predetermined criteria by the researchers in accordance with the research objectives.

The informants or subjects in this study are the people who know the ins and outs of Lubuk Larangan in Tanjung Belit Village, Kampar Kiri Hulu District, Kampar Regency which are ninik mamak or the tradition figure, community leaders, and head of the village (key informant), as well as some local citizens who know and participate in the management or preservation of Lubuk Larangan.

The data collection techniques used in this study are as follows: (1) Observation, the ability of a person to use his/her observations through the work of the eye sensor assisted with other senses. Before carrying out the observation, the researchers will conduct an approach to the subject of the research so that there is an intimacy between researchers with research subjects. (2) In-depth interviews, a method in the form of verbal communication or conversation to obtain information. An interview is conducted by two parties, the interviewer who asked questions and respondents who gave answers to the question. Interviews are used to have a communication with research subjects and to obtain necessary data. In-depth interview technique is used to obtain information directly from research subjects through a series of question and answer directly related to the subject matter. In this study, the interview was conducted by using guided free interview guidelines. The guided free interview is to ask free questions, meaning that the question is not fixated on the interview guidelines which then can be developed in accordance with the conditions of the field. In conducting this interview, the interviewer carries a guide that contains only an outline of the things to be asked. The researchers will conduct an in-depth interview to the research subjects in the form of a free interview. That way, the obtained information is expected to reveal facts about the history and management of the tradition.

Data analysis is the process of arranging the sequence of data, organizing it in a pattern, categorization, and basic description unit. According to Bogdan and Biklen, data analysis is working the data, organizing and sorting it into manageable units, synthesizing it, searching and finding the patterns, sorting of what is important and what is learned, and, lastly, deciding what can be told on others. The technique of data analysis used in this research is referring to the concept of Milles \& Huberman which is an interactive model that classifies data analysis in three steps, namely: 1. Data Reduction. It is a process of sorting, focusing attention on simplification, abstraction, and transformation of coarse data from written records in the field; 2. Display data. The data is arranged in such a way as to provide the possibility of drawing a conclusion and taking action. The usual form used in qualitative data is, first, in the form of narrative text. Associated with display data, researchers present the data in the form table; 3 . Verification. In this research, the meaning of the collected data will be disclosed. From the data, a tentative, blurred, rigid, and dubious conclusion will be obtained so that it needs to be verified. Verification is done by reviewing the reduction before the data is displayed in disc form.

\section{Research Results and Discussion}

\subsection{The Management of Lubuk Larangan}

Ecological wisdom and local wisdom are the knowledge obtained from abstraction, experience and active adaptation to a distinctive environment. Environmental wisdom embodied in these 3 forms is understood, developed, guided and inherited from generation to generation by the supporting community. The wise and sustainable management of the environment was developed considering the importance of social environmental functions in ensuring the survival of the community. The benefits that people gain from their environment, especially those who are at the economic level of subsistence, make them immensely depend on their environment [15]. 
In Kampar Kiri Hulu subdistrict, there are several villages that have a local wisdom such as Lubuk Larangan. According to the information from community leaders in Tanjung Belit Village, Lubuk Larangan began in 1980. However, it was formed on a mutual agreement. This was made clear by one of the informants, whose name is $\mathrm{Mr}$. Sudirman.

"Lubuk Larangan developed after our village was hit by a major flood in 1978. This was decided on the basis of deliberation and consensus among the officials (Chiefs of The Tribal Council) along the shoreline of Kampar Kiri or the river of Subayang". (Interview, April 2017).

At the beginning of formulating the Lubuk Larangan, the village community gathered; including the ninik mamak (customary leaders and elders), young men and the village government officials. They discussed the village financial problem occurring in their area as the finance was very minimal at the time, while they could not expect much from the government. When they really need to build and develop, the community came up with an idea of making budgetary income through the program of making Lubuk Larangan; as stated by Ms. Nuriyah in the following statement:

"The procedure for the Lubuk Larangan is the result of cooperation between the ninik mamak, the village head and the community through collective discussion to preserve the Lubuk existing since the past time" (interview, April 2017)

After the community discussion on the Lubuk Larangan program was approved by the local residents, they arranged for the manager, planned and determined the area of the Larangan. After the location had been established, the "Tiga Tungku Sajorangan" was assembled; it consists of the customary leaders (Ninik Mamak), religious leaders (Alim Ulama), and community leaders (Cerdik Pandai). They conduct another meeting to discuss rules and punishment should someone violate the rules in the future. In the meeting, they also discussed and recited prayers in the form of judgments which were decided by several oath policies which consisting of:

Rules and Punishment of Oath. These were taken as a process of preserving Lubuk Larangan so that the community could adhere to the mutually agreed rules related to Lubuk Larangan.

According to Ms. Nuriyah in her statement:

"Whoever damages and disturbs the area of Lubuk Larangan, they will bear the consequences of the oath and prayer that have been agreed upon: they will suffer from distended belly as a consequence of the violation. Meanwhile, people coming from other regions, unknown people, and people who do not know the rules are not obliged by the oath and punishment. "(interview, April 2017).

Social punishment. In addition to rules and oath punishment, there will be social punishment for the violators, as said by Mr. Sudirman in the following statement:

"Ke bukit tidak berangin, kelurahan tidak berangin". This is a proverb meaning that in any customary/ community activities being held, the violator will be excluded from committing a customary violation. (Interview, April 2017).

After the policy and oath were taken, the villagers and their surrounding began to protect the Lubuk Larangan together. So, the fish that naturally existed in the Lubuk Larangan were left as they were until the specified time

"The fish seeds are obtained from the river itself, they are not produced. There is no cost incurred. The fish seeds are native to the river. The distribution of fish harvested from the Lubuk Larangan pond is distributed to the community evenly. The ponds harvesting time is approximately twice a year." (Interview, April 2017)

Based on these thoughts, the development of Indonesian marine conservation areas in Indonesia is a very important necessity for public waters, in order to conserve and make the utilization of these aquatic fish resources sustainable. The initial activity in the framework of developing this public water conservation area is identifying the potential fish resources and their habitat.

Wirawan and Dermawan in [26] asserted that in the fisheries resource management strategy, there are 3 specific components, they are: 1) 'Full Reserve' (comprehensive protection) in the form of full protection against a prohibited area (Full Protected Area). 2) 'Species Spesific Refugia' (Restrictions on certain species catches). 3) 'Effort Or Behavioral' (the decrease in efforts to catch), through restrictions on the type of fishing gear, fishing quota, season regulation and others, for instance. When viewed from the management pattern, Lubuk Larangan in Kampar Kiri Hulu Subdistrict belongs to the 'Effort Or Behavioral' category, that is the decrease in efforts to catch, with the $6.750 \mathrm{~m}^{2}$ wide Lubuk Larangan in Tanjung Belit Village.

\subsubsection{The Physical Condition of Lubuk Larangan}

Every village in Kampar Kiri Hulu District has Lubuk Larangan from 1 to 2 areas. The village of Tanjung Belit has 1 area of Lubuk Larangan. Tanjung Belit village is only $\pm 3 \mathrm{Km}$ from the capital city of Gema Village. Information about the bans from every village in Kampar Kiri Hulu sub-district is shown in Table 1.

Table 1. The Condition of Lubuk Larangan in Tanjung Belit Village (Depth, Water Clarity, Length, and Width of the River

\begin{tabular}{|l|l|l|}
\hline No & Information & Tanjung Belit Village \\
\hline 1. & Depth (in Rainy Season) & $4.5-5.5$ \\
\hline 2 & Water Clarity & $44 \mathrm{~cm}$ \\
\hline 3 & Length of Lubuk Larangan & $150 \mathrm{~cm}$ \\
\hline 4 & The width of Lubuk Larangan & $45 \mathrm{~m}$ \\
\hline 5 & Lubuk Larangan Area & $6.750 \mathrm{~m}^{2}$ \\
\hline
\end{tabular}

Source: Secondary Data, 2017 
In the boundary of Lubuk Larangan area, the community gives a sign in the form of rope stretching from the edge of the river and across. The use of the rope is to know the location of Lubuk Larangan in each village. As Mr. Sudirman has said:

"Lubuk larangan tidak memiliki pemabatas seperti pagar, dinding pukat dan sebagai lainnya, melainkan hanya ditandai dengan tali tambang yang dibentangkan ke seberang sungai dengan ketinggian dari permukaan sungai \pm 4 meter yang diikatkan pada pohon karet atau pada kayu lainnya yang diperkirakan tidak akan menghalangi orang hilir- mudik di sungai yang melakukan aktivitas disekitar Sungai Subayang"

"Lubuk Larangan does not have such limitations as fences, trawl walls, and others, it is only marked with ropes stretched across the river from the surface of \pm 4 meters and tied to rubber trees or other woods that are expected to not prevent the downstream people in the activities around Subayang River" (interview, April 2017)

The criteria for the area of Lubuk Larangan itself including:

1. The depth of the river. The area is selected due to the consideration that when the dry season comes, the fish can still alive and breed. There is also a container as a place for more fish.

"Lubuk larangan ini memiliki kedalaman pada musim hujan sekitar 4,5- 5,5 meter. Biasanya ikan lebih memilih kawasan yang dalam untuk tempat hidup dan berkembangbiaknya ikan-ikan besar, seperti Ikan Tapa, Geso, Belida dan lainya. Dalam bahasa lokal kami sering disebut "bangkagh ikan" yang artinya sarang ikan"

"In the rainy season, this Lubuk Larangan has a depth of 4.5 to 5.5 meters. Usually, the fish prefer deeper areas for living and breeding large fish, such as Tapa Fish, Geso Fish, Belida Fish, and others. In the local language, we often called "bangkagh ikan" which means fish nest" (Sudirman, interview April 2017)

2. Close to residential areas so that the supervision can be done at any time by the local community.

\subsubsection{Pengelolaan Lubuk Larangan}

The management procedures referred are supervision, regulation and sanctions, harvesting, and sales. The management of Lubuk Larangan aims to protect the prohibition area. According to Rokhmin [21], management is a term derived from the word "manage" which means a series of efforts aimed at exploring and utilizing everything that is owned effectively and efficiently in order to achieve certain goals that have been planned previously. This means that in utilizing the natural resources of local wisdom, the government should pay attention to environmental management. The community awareness in Kampar Kiri Hulu District over the natural resources is well managed. This is a form of concern for the environment and the future. Good management by the community will produce good results. This is clarified by one of the informants in the study which said:

"Lubuk larangan di kelola secara bersama, tidak ada daftar piket atau petugas yang secara resmi mengelola lubuk larangan. Semua warga desa Tanjung Belit memiliki kewajiban yang sama yaitu selalu menjaga lubuk larangan dari segala ancaman yang dapat merusak lubuk larangan"

"Lubuk Larangan is managed together. There is no duty or officers who officially manage the depths of the area. All villagers of Tanjung Belit have the same duty to always keep Lubuk Larangan against any threats that can damage the area" (Nuriyah: interview, April 2017).

The management of the area is done jointly by the community, ninik mamak, and village council. In the management, there is no division of tasks such as chairman, treasurer, and secretary. However, in the harvest time, they divide the tasks for ninik mamak, village council, youth organization, and community jointly. The organizational structure is only the controlling members. The harvest is done on the bottom of Lubuk Larangan. The harvesters are all villagers who are willing to help and participants are those who will buy the harvest results whether it is from the village or outside the village.

"Ketika Panen, akan ada persiapan rapat yang dilakukan untuk menentukan panitia yang bertugas dalam hal pemanenan biasanya panitia tiap tahun berganti dari tahun sebelumnya. Jumlah panitia yang bertugas biasanya berkisar 35-50 orang.

"In the harvest time, there is a preparatory meeting held to determine the committee who will be on duty. Each year, the committee will be changed. The number of the committee on duty is usually around 35-50 people" (Sudirman, interview April 2017)

Basically, the management has the aim to improve the welfare of the whole society (social well-being) in a sustainable way especially local community who live on the edge of the river. Therefore, in the utilization of public water resources, the ecological aspects in terms of resource sustainability and ecosystem function should be considered as the main basis to achieve such welfare. The supervision and management of Lubuk Larangan in Kampar Kiri Hulu District are carried out by the surrounding community, and most importantly, by the ninik mamak in the village.

\subsubsection{Rules and Sanctions}

The management of Lubuk Larangan is very clear and resolute. Regulations are made based on the mutual agreement so that it is not absolute and can be changed according to mutual needs and directly passed down through generations and obeyed by all levels of society, 
thus becoming local wisdom.

There is a sanction of someone who violated Lubuk Larangan; they will get a curse. The following statement is said by Mr. Sudirman:

"Sanksi dibuat ketika pembentukan lubuk larangan, terdapat dua macam hukuman yaitu hukuman sumpah dan hukuman sosial. Hukuman sumpah yaitu berupa perut gembung yang tidak bisa disembuhkan bagi orang yang mengambil ikan dilubuk larangan. Kedua, hukum sosial berupa "Ke bukit tidak berangin, kelurahan tidak berangin" yang artinya, apapun kegiatan adat/kegiatan masyarakat setempat, maka si pelanggar tidak akan ikut sertakan/dikucilkan, karena telah melakukan pelanggaran adat. Sosialisasi tentang aturan tersebut, dilakukan ketika pertama kali pemberlakuan lubuk larangan di Sungai Subayang

"Sanctions are made Lubuk Larangan was made. There are two kinds of punishment such as curse and social punishment. The curse is in the form of a bloated stomach that cannot be cured for the person who takes the fish in the prohibited area. Second, the social punishment of "Ke bukit tidak berangin, kelurahan tidak berangin" which means that whatever activities of local customs carried out, the offender will be excluded because they have committed a customs violation. The socialization of this rule is done in the first imposition of Lubuk Larangan on Subayang River" (interview, April 2017)

The punishment or action is given to those who violate the rules. Based on the deliberation, at the beginning of the formation of Lubuk Larangan in each village of Kampar Kiri Hulu District, any person who violates the rules intentionally or secretly will be punished.

If anyone violates the rules, he/she will get sanction in the form of the bloated stomach which cannot be healed and can lead to death. This happens because the people have sworn jointly to always keep the area of Lubuk Larangan. These sanctions are not written but are understood and obeyed by the whole society. It is known that the sanctions are done through prayer.

"Hukuman atas sumpah itu diberikan lewat bacaan surat yasin dan doa bersama oleh warga Desa Tanjung Belit. Sanksinya perut gembung, itu adalah sanksi adat, tentang sanksi ini disebar melalui cerita dari mulut ke mulut"

"The punishment of the oath is given through the reading of Yasin and prayer done together by the villagers of Tanjung Belit. The severity of the bloated stomach is a customary sanction. It is spread through the story by word of mouth" (Julfita, interview: April 2017).

There are few myths that accompany the beliefs of this mysticism at Lubuk Larangan since this area is settled. One of which is the belief that the fish are abundant because once the fish enter the area, they will be difficult to exit again.

\subsubsection{Harvest Time}

When the dry season comes, people will notice the coming of the harvest time which is held around June, July, or August by looking at the physical condition of the Lubuk Larangan and the size of the fish to be harvested. This was made clear by one of the informants in the study.

The activity of harvesting or batobo mancokau ikan tradition of Lubuk Larangan is implemented based on the consultation from the custom among all ethnic groups in the village of Tanjung Belit. In the density of batobo mancokau ikan culture, the day of the harvest will be determined as well as the committee in which is decided by the holder of the customary power which is Datuok Godang.

"Pemanen ikan dilakukan setahun sekali sekitar awal bulan Juni-Agustus tergantung kondisi air sungai dan cuaca. Biasanya kegiatan panen atau biasa kami sebut dengan Batobo mancokau ikan ini dilakukan pada hari jum'at dengan alasan hari baik".

"Fish harvesting is conducted once a year around the beginning of June-August depending on the water of the river and weather. Usually, the harvest or Batobo mancokau ikan is done on Friday because we consider it as a good day" (Julfita, interview April 2016).

Customary density will determine the organizing committee. There is no specific criterion in the selection of the committee in this area. Only those who are willing to contribute the energy can be appointed as a committee. The committee of the harvest includes ninik mamak, village council, youth organization, and community which are compiled and decided jointly. 


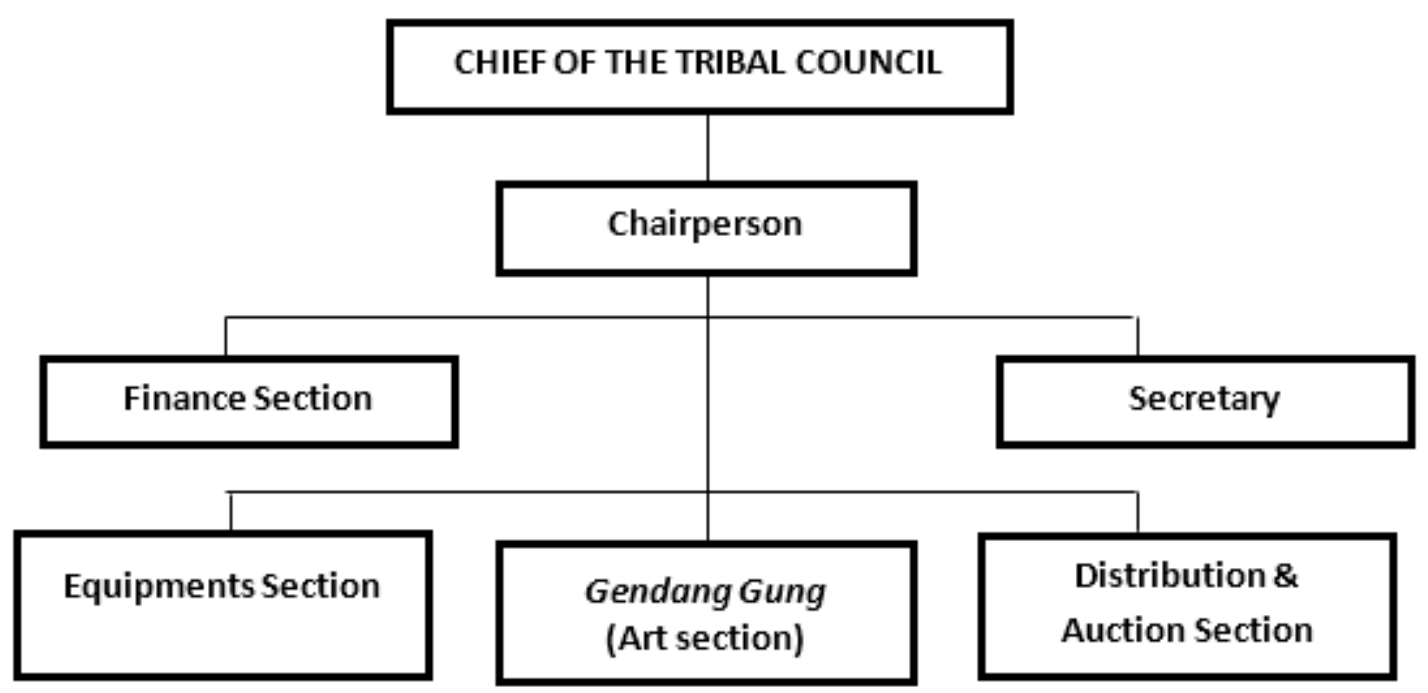

Figure 2. The Lubuk Larangan structure of fish harvest and auction committee

Figure 2 explains the harvest structure in the administration of adat so that each committee member has the following duties and obligations.

1. The chairperson is responsible for harvesting, from the preparation until the due time.

2. The finance section is tasked with recording participants registration with the secretary, reporting the acquired funds in the committee meeting, and allocating the distribution of funds according to the agreement made at the meeting.

3. The secretary is in charge of preparing the administration of harvesters in the form of invitations, harvest rules and signs of participants.

4. The equipment section is preparing the equipment needed at the harvesting time, such as the loudspeakers, tables, chairs, participant tents and harvesting tools.

5. The Gendangan is an art group presenting a special performance at the harvesting time.

6. The distribution and auction section is tasked with collecting harvest yields and distributing them to the bidders.

This committee arrangement is not permanent. After the harvest is completed, the committee is usually disbanded. The committee responsible for dividing and supervising will be formed again at the next harvest. Technically, the committee and participants normally use several tools for harvesting, they are:

1. A fishing net of which the mesh size is 0.5 to $1 \mathrm{inch}$, the length is upto 40 meters, and the width is 2 meters.

2. A casting net of which the mesh size is 0.5 to 1 inch, with the length of 4 meters. A casting net is a simple fishing tool and does not cost a lot of money in the making, the material is made of multifilament nylon or monofilament; it's diameter ranges from $3-5 \mathrm{~cm}$ and the ball of the ballast is made of tin.
3. The technical procedures of Lubuk Larangan fishing or harvesting is as follow: a fishing net (the length is 35 to 40 meters) is set from end to end at the Lubuk border. Then, it is dragged to the center together by 10 to 15 people so that the initial length of the Lubuk Larangan which is 150 to $200 \mathrm{~m}$ is reduced to approximately $50 \mathrm{~m}$ (after being brought to the center/ being reduced). As the size of the Lubuk Larangan is changed to $50 \mathrm{~m}$, the participants immediately throw the casting net.

There are various types of fish caught; those that are usually caught at the harvest time are Barau Fish, Tapah Fish, Kapiek Fish, Baung Fish, Geso Fish, Limang Fish, Jangga Fish, Pantau Fish and others. However, the small Pantau fish passing through the nets are usually released back to the water because these fish are useful as the river cleaners; they usually eat the moss around the bottom of the bark. In Tanjung Belit village, catching any fish in Lubuk Larangan is not allowed. People can only catch the fish for consumption, which is large in size/ weighs 250 grams.

"Ikan yang ditangkok waktu pelaksanaan batobo mancokau ikan harus ala godang, paling ketek sagodang ukuran ompek jayi atau sekitar saparompek mato; supayo ikan yang ketek bisa berkembangbiak lai. Dan ikan yang ado lubuok laang kami indak abi"

"In fish harvesting (the tradition of batobo macokau ikan), the size of the fish allowed to catch is at least equivalent to the size of four fingers or around 250 grams; so that the small fish can breed to prevent them from being completely gone." (Sudirman, Interview on April 2017).

In fish harvesting, people outside the village of Tanjung Belit may also help as long as it is appropriate and does not violate the existing rules, i.e. The fishing should not use chemical substances. Usually, the outside community 
coming to witness the harvesting activity are from the Taluk Kuantan, Bangkinang, Pekanbaru, and Lipatkain area.

\subsubsection{The Sale}

There are various types of fish caught; those that are usually caught at the harvest time, such as Barau Fish, Tapah Fish, Kapiek Fish, Baung Fish, Geso Fish, Limang Fish, and Jangga Fish. After the harvest, the fish are specified according to their sizes. If the fish is under the category of one fish weighing above $1 \mathrm{~kg}$, they are sold to the people outside the village or the region. Whereas for those under the category of one fish weighing under $1 \mathrm{~kg}$, the fish are sold to the community around the village. The catch will be auctioned or sold to the communities around and outside the village with mutually agreed price. The harvested fish price in Lubuk Larangan has been set by the committee when they held a meeting to divide their tasks and to determine the harvest day.

"The price for the category of one fish weighing under 1 $\mathrm{kg}$ (for the people around the village) is set to IDR $10,000 / \mathrm{kg}$ and the (price for) people from outside the village are set to IDR $15,000 / \mathrm{kg}$. As for the categories of tapah and baung fish, of which one fish weighing more than $1 \mathrm{~kg}$, the committee set the price to IDR $40,000 / \mathrm{kg}$ (for people outside the area)". (Sudirman, Interview on April 2017)

The money from the harvested fish sale will be put into the village treasury to develop the village; the construction of mosques receives $(40 \%)$, the orphans receive $(25 \%)$, the youths and mothers joining PKK - a family welfare program - receive (35\%). Religious activities are granted higher fund than the others.

According to Julfita: "the harvest yield fish are sold at the prices set by the committee, and the proceeds from the sale are allocated to the village treasury to develop the village, such as the construction of mosques, compensation for orphans. Now that our mosque is being enlarged, the funds for the renovation of the mosque are mostly from the proceeds from the sale of fish harvested in the Lubuk Larangan. This proves that the formation of Lubuk Larangan has made the development in our villages more thriving." (Interview on April 2017).

The people outside the village, who usually come to witness and buy Lubuk Larangan yields, come from the Taluk Kuantan, Bangkinang, Pekanbaru, and Lipatkain area. Technically, one of their representatives is given information directly by the harvest committee or from the village community when the Lubuk Larangan is to be harvested.

\subsection{Local Wisdom Contained in the Management of Lubuk Larangan Tradition}

Local Wisdom which is also known as Local Genius is the first term introduced by Quaritch Wales [4]. Haryati
Soebadio asserted that local genius is also the cultural identity; the identity/ personality of the national culture allowing the nation to take in and to manage a foreign culture according to their own character and abilities.

Sibarani in [22] also explained that local wisdom is the wisdom or original knowledge of a community originated from the noble values of cultural traditions to regulate the order of people's lives. Local wisdom can also be defined as a local cultural value that can be used to wisely regulate the order of people's lives.

So in a broad sense, it can be interpreted that local wisdom is formed as a cultural prominence of the local community in relation to geographical conditions. Local wisdom is a product of the past culture that should continuously be the way of life. Although it is of local value, the values embodied in it is considered to be very universal.

Substantially, local wisdom is the prevailing values in a society. Values are believed to be true and become a reference in the daily behavior of local people. Therefore, it is reasonable to say that local wisdom is an entity that determines the dignity of the community. It means that local wisdom, which contains the elements of creativity and local knowledge of the elites and the community, is what determines the development of society civilization.

In our society, local wisdom can be found in customary traditions, songs, proverbs, sasanti (praise), admonitions, slogans, and ancient books that are inherent in our daily behavior. Local wisdom is usually reflected in the people's life habits going on for a long time. The sustainability of local wisdom will be reflected in the values applied in certain groups of people. These values are certain community groups' way of life, which will commonly be their inseparable part of life. This can be observed through their daily demeanor and behavior. Similarly, the Tanjung Belit village community's local wisdom appears in the management of Lubuk Larangan.

Some local wisdom used to manage the environment in the area of Lubuk Larangan in Subayang River, Tanjung Belit Village, Kampar Kiri Hulu District, Kampar Regency, Riau Province are:

\section{1) Fish should not be taken prematurely}

The fish in the area should not be lured or taken prematurely for any reason because it is in accordance with the rules and oaths that have been agreed upon. Lubuk Larangan is owned by all villagers of Tanjung Belit and has many rules and procedures until the time of harvesting. In the process of harvesting, all members of the community are involved which prove that the people of Tanjung Belit Village have a high solidarity and is a civilized society.

\section{2) Ethno-technology}

Ethno-technology can be defined as the whole equipment owned by a particular society or social group along with procedures to achieve the goal or solve certain 
problems in dealing with a particular situation and environment. This ethno-technology is produced and developed by the society or social group itself and passed from generation to generation over a relatively long period of time. In this context, ethnoscience and ethno-technology are the systems of knowledge and technology possessed by a society, a nation, a particular social group, which generally have certain special features distinguishing it from the system of knowledge and technology in other societies. Ethno-technology is a simple tool used by traditional society such as Fish Rifle, Spear, Lukah/Bubu, Nets, Fishing bamboo, Rawai, Sawuak-sawuak, Bamboo Tanggok, Pasok, Simotiak. These tools are made of natural and organic materials such as Woods, Rattan, and Roots. All of those are not made of iron, nails, and wires or other hazardous materials. This tool only takes advantage of human power which can be utilized individually or in the group. The use of these tools is environmentally friendly and there are no negative impacts on fish and the environment. Similarly, at harvest time, people only use simple equipment such as nets. Examples of using environmentally friendly fish harvesting equipment are as shown in Figure 3, where people harvest fish using ethno technology that does not damage the environment.
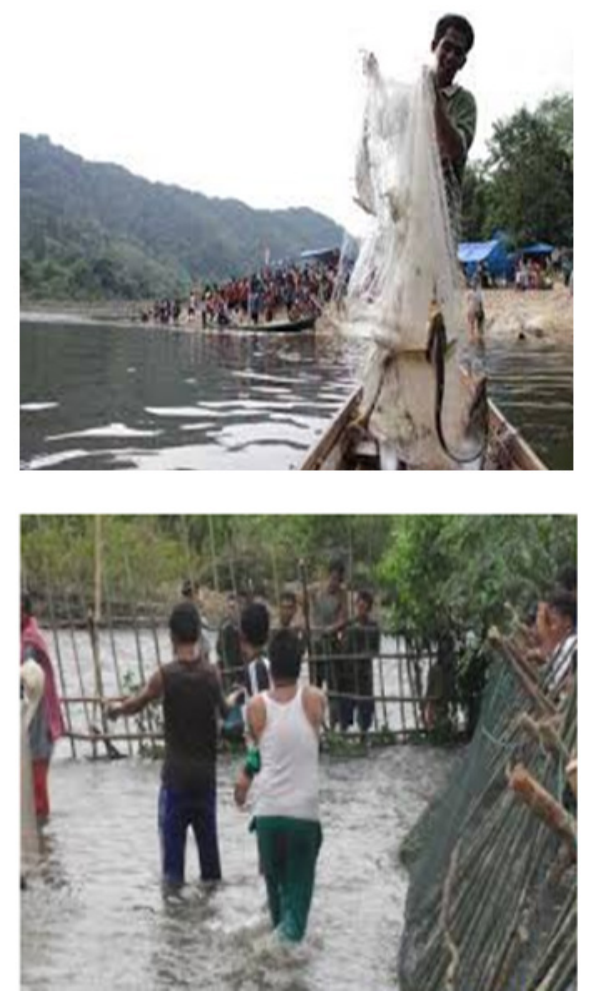

Figure 3. The use of ethno-technology in fish harvesting activities in Lubuk Larangan

\section{3) Maintaining the River Banks Vegetation}

Maintaining the vegetation on the river banks has been practiced by the local people in Tanjung Belit Village by not cutting down forests carelessly. Moreover, Lubuk
Larangan is located in Bukit Rimbang Baling Wildlife Reserve. It is an area which is rich in the natural ecosystem. The people in Tanjung Belit Village are very strict in the preservation of the river water ecosystem. The community is aware of the importance of maintaining the river and forest. This is because they depend their lives on the river, both for household needs and transportation.

The nature conservation agency, World Wildlife Fund (WWF) of Riau, considers the tradition of Lubuk Larangan as the local wisdom of Tanjung Belit Village which should be maintained to preserve the rivers and forests. WWF of Riau spokesperson, Syamsidar, said that through the tradition of Lubuk Larangan, the residents of Tanjung Belit Village has the vision to save the environment. Moreover, this village is in the buffer zone of the Bukit Rimbang Baling Wildlife Reserve. To keep the river fresh and uncontaminated, people started the action by protecting the forest well. The action taken by the local community to protect the forest is getting good results as shown in Figure 4, where the condition of the Subayang river in Tanjung Belit Village seems to be improving and clean.
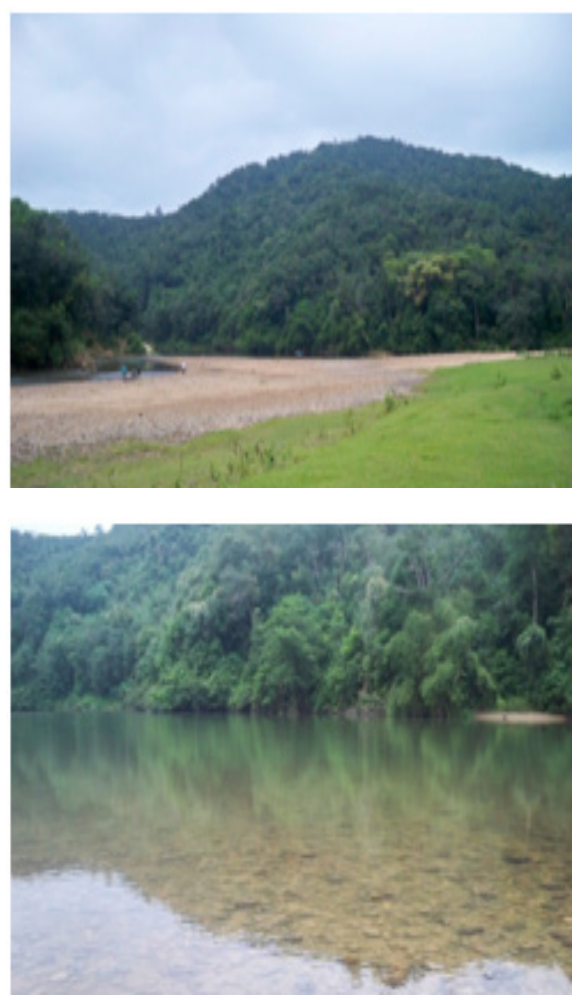

Figure 4. The Vegetation Condition of Subayang River Banks in Tanjung Belit Village

The people are aware of the impact of forest encroachment which will cause an increasingly rapid flow of water that resulted in flooding. As a result, fish cannot survive in one place. Thus, according to Syamsidar, the conserved natural forest will preserve the biodiversity population that inhabits Bukit Rimbang Baling, especially for Sumatran Tiger. 
4) Only big fish that can be caught. In the village, not all fish can be caught, only big fish that is at least four-finger-sized or 250 grams/fish.
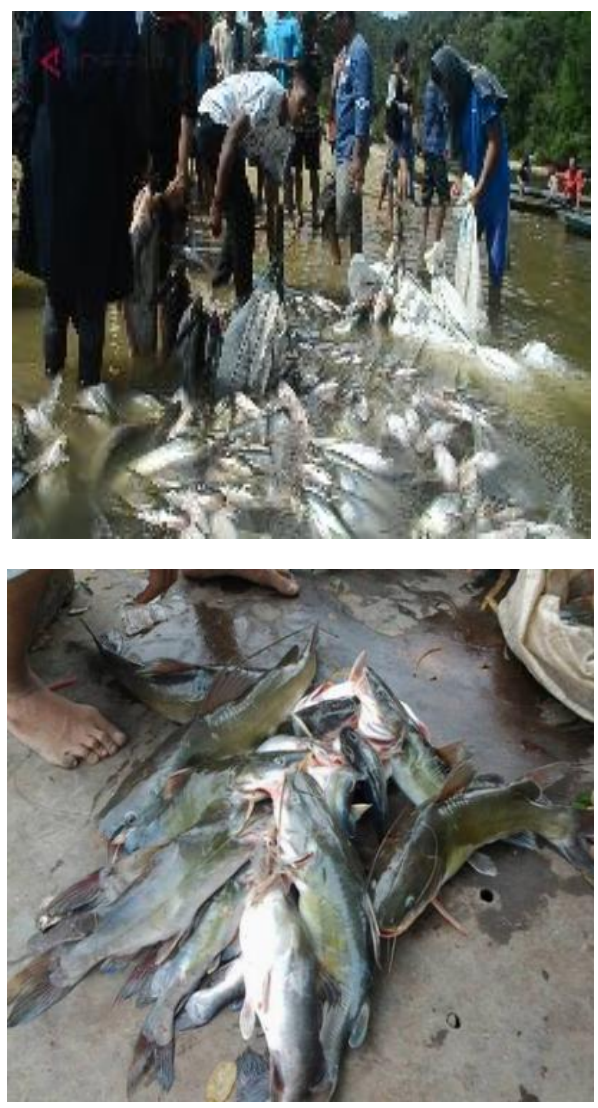

Figure 5. Fish Harvest in Lubuk Larangan

As shown in Figure 5, local people only harvest fish of a certain size (already large) and forbid harvesting fish that are still small in size. This prohibition is applied to give an opportunity for small-sized fish to grow and breed. Besides, catch the larger fish will give a tastier and more savory meat and that the fish in the area will not extinct.

\subsection{The Community Efforts in Preserving the Lubuk Larangan Tradition}

The Lubuk Larangan tradition in Tanjung Belit Village has directly raised public awareness to protect the forests and rivers. Moreover, the area is located in the Bukit Rimbang Baling Wildlife Reserve which is rich in natural ecosystems. The community is well aware of the importance of maintaining the river. The reason is that the residents around the area depend on the river until the present time; both for their household needs and transportation. Village officials are very concerned about the potential of environmental damage due to illegal mining and encroachment. For this reason, they designed ecotourism regulations while maintaining the nature preservation sustained by the local village community.

As stated by the World Wildlife Fund (WWF) Nature
Conservation Institute of Riau, the Lubuk Larangan tradition is a local wisdom of the village community that is ought to be maintained, in order to preserve the rivers and forests. Through the Lubuk Larangan tradition, the residents of Tanjung Belit Village have a vision to save the environment; moreover, the village is in the buffer zone of Bukit Rimbang Baling Wildlife Reserve.

To keep the river protected and uncontaminated, the residents start by protecting the forests. They are aware of the impact of forest encroachment resulting in increasingly rapid river water flows, which have caused flooding. As a result, even the fish cannot survive in one place. The preserved natural forest will maintain the biodiversity population inhabiting the Rimbang Baling Hill, especially the Sumatran Tigers. Due to the residents' concern to protect the river, the forests are also directly protected. It is expected that Tanjung Village can be more well-known by the wider community for its tourist attractions and that the government shows further concern for the development of Tanjung Belit Village.

According to Mr. Yusri, a villager, the effort that will be made for the local wisdom of the Lubuk Larangan culture is as follows:

"... Yes ... One of the ways to preserve Lubuk Larangan is to prohibit poisoning, electrocuting the fish; because it is not only the big fish that die, but also the small ones." (Interview, April 2017)

Mr. Afrizal, the $\mathrm{IV}^{\text {th }}$ village chief of Tanjung Belit Village, also expressed his hopes for the Lubuk Larangan:

"... hopefully, this tradition continues to posterity. So even our grandchildren can eat our own fish ..." (Interview, April 2017).

Meanwhile, Mr. Siamri as Datuk Godang (the highly respected elder) also stated similarly:

"(The effort) ... all the villagers protect it together, so the effort proceeds well; in that the fish continue to exist and there is a lot of extra income for the village. So the outsiders also know a great deal of our traditions. So that many people will visit." (Interview, April 2017).

In conclusion of the interview results, the communities realize that in maintaining the tradition of Lubuk Larangan local wisdom, they need to view it from the methods. The Subayang river, which is used as a source of livelihood and also the source of economy for the village residents of Lubuk Larangan tradition, is utilized by the community to catch fish, of which the benefits are for the community.

This is because in maintaining the river water and the fish living in the Subayang river, the community protect the environment. The river water utilized by many local residents should not be damaged and polluted with toxic substances or irresponsible humans, both the native villagers and ignorant immigrants who want to irresponsibly catch the fish, without considering the adverse effects on the ecosystem and the surrounding 
environment.

The other effort in maintaining the local wisdom (local genius) of Lubuk Larangan is inherited continuously from the ancestors and then continued by the ninik mamak and traditional religious leaders, as well as the alim ulama (Muslim religious leaders) in order to keep its authenticity by preserving it through cooperation with the existing natural conservation institutions or WWF. In that, the whole community, including the younger generation of villages and the government along with the village head, can contribute properly according to the customary law and habits that are often performed by the residents of Tanjung Belit Village; and this can keep progressing with directed and orderly environmental cycles for the continuity of human life as well as for the future posterity.

\section{Conclusions}

Based on the results of the research, it can be concluded that (1) The management of Lubuk Larangan is intended to protect the prohibited area. The management procedures include the supervision, regulation, sanction, harvesting, and sales. (2) The forms of local wisdom contained in the management of Lubuk Larangan tradition are 1). Fish should not be taken prematurely, 2). Catch the fish with Ethno-technology, 3). Maintain the vegetation of river banks, 4). Only big fish that can be caught. (3) The efforts to maintain local wisdom (local genius) of Lubuk Larangan are to maintain the river unpolluted by keeping the forest ecosystem and preventing forest encroachment as well as maintaining the river biodiversity population by non-poisoning the fish, not harvest the small fish, and cooperate with various parties such as non-governmental organizations like WWF and local government.

Based on the findings obtained in this study, the suggestions given are: (1) For the community, it is suggested to synergize with each other in maintaining, preserving Lubuk Larangan with the principle of "Rescuing Environment Based on Local Wisdom" by involving all aspects or community groups including the younger generation. (2) Lubuk Larangan in the village of Tanjung Belit is one example of nature conservation so that it should be published to other areas that have the same geographical condition such as Watershed Area thus it can be used as an example in managing and conserving the environment. This can be done through cooperation with various parties or stakeholders such as NGOs, local and national media, and in coordination with local government such as tourism or environmental office. (3) There should be an assistance or intervention of local government related to the preservation and management of Lubuk Larangan which refers to the Law number 32 of 2009 in concern to Environmental Protection and Management.

\section{REFERENCES}

[1] Schneider, R. (2016), "Heroes, superheroes, and policy outcomes: An alternative view of leadership of public organizations", International Journal of Organization Theory \& Behavior, Vol. 19 Issue: 1, pp.60-78. https://doi.org/10.1108/IJOTB-19-01-2016-B007

[2] Adams, A. (2007), "Developing Leadership Wisdom", International Journal of Leadership in Public Services, Vol. 3 Issue: 2 , pp. 39-50. https://doi.org/10.1108/17479886200 700012

[3] Ataupah, (2004), Peluang Pemberdayaan Kearifan Lokal Dalam Pembangunan Kehutanan, Kupang.

[4] Ayatrohaedi. (1986), Kepribadian Budaya Bangsa (Local Genius), Pustaka Pelajar, Jakarta.

[5] Firdaus, M. and Huda, M.H., (2015), "Pengelolaan Sumberdaya Ikan Di Sungai (Studi Kasus: Di Kabupaten Pesisir Selatan, Provinsi Sumatera Barat)", Buletin Ilmiah "MARINA" Sosial Ekonomi Kelautan dan Perikanan, Vol. 1 No. 1, pp. 41-47, Available at: http://ejournal- balitbang.k kp.go.id/index.php.

[6] Fuller, C. and DelliSanti, D. (2017), "Spillovers from public entrepreneurship: a case study", Journal of Entrepreneurship and Public Policy, Vol. 6 Issue: 1, pp. 72-91. https://doi.org/10.1080/23322373.2016.1206802

[7] Garah, W., I. Beekun, R., Habisch, A., Lenssen, G. and Adaui, C.L. (2012), "Practical wisdom for management from the Islamic tradition", Journal of Management Development, Vol. 31 Issue: 10, pp.991-1000. DOI: 10.110 $8 / 02621711211281906$

[8] Gowda, K., Sridhara, M.V. and Rajan, S. (2008), "Planning and management of parks and green areas: The case of Bangalore metropolitan area", Management of Environmental Quality: An International Journal, Vol. 19 Issue: 3, pp. 270-282. https://doi.org/10.1108/14777830810 866419

[9] J. Adler, N. (2014), "Global Wisdom and the Audacity of Hope: Designing Global Networks in a World of Complexity Based on Adler's work with Uniterra and Adler (2007; 2006)", in Joyce S. Osland , Ming Li , Ying Wang (ed.) Advances in Global Leadership (Advances in Global Leadership, Volume 8) Emerald Group Publishing Limited, pp.19 - 44. DOI: 10.1108/S1535-120320140000008006

[10] Keraf, S. (2005), Etika Lingkungan Hidup, Kompas Penerbit Buku, Jakarta.

[11] Kletz, P., Almog-Bareket, G., Habisch, A., Lenssen, G. and Adaui, C.L. (2012), "Practical wisdom for management from the Jewish tradition", Journal of Management Development, Vol. 31 Issue: 9, pp. 879-885. DOI: 10.1108/ 02621711211259929

[12] Kusumasari, B. and Alam, Q. (2012), "Local wisdom-based disaster recovery model in Indonesia", Disaster Prevention and Management: An International Journal, Vol. 21 Issue: 3, pp.351-369. DOI: 10.1108/09653561211234525

[13] Lavan, I. (2002), "NLP in business - or more than a trip to the zoo", Industrial and Commercial Training, Vol. 34 Issue:

5, pp. 182-187. https://doi.org/10.1108/0019785021043710 
[22] Sibarani, R. (2012), "Batak Toba society's local wisdom of mutual cooperation in Toba Lake area: a linguistic anthropology study", International Journal of Human Rights in Healthcare. Lokal dalam Pengelolaan Sumber Daya Alam di Tapanuli Selatan [Re-developing Local Wisdom in Natural Resources Manaement in South Tapanuli]", Antropologi Indonesia, Indonesian Journal of Social and Cultural Anthropology, Vol.29 No.3, pp.239.

[15] Mitchell, B. (2002), Resource and Environmental Management, 2nd Edition, Routledge, New York.

[16] Naughton, M., Habisch, A. and Lenssen, G. (2010), "Practical wisdom in management from the Christian tradition", Journal of Management Development, Vol. 29 Issue: 7/8. https://doi.org/10.1108/jmd.2010.02629gaa.002

[17] Parwati, A., Purnaweni, H. and Anggoro, A.D., (2012), "Nilai Pelestarian Lingkungan dalam Kearifan Lokal Lubuk Larangan Ngalau Agung di Kampuang Surau Kabupaten Dharmasraya Provinsi Sumatera Barat", Prosiding Seminar Nasional Pengelolaan Sumberdaya Alam dan Lingkungan Semarang, 11 September 2012.

[18] Peters, B.G. (2008), "The Napoleonic tradition", International Journal of Public Sector Management, Vol. 21 Issue: 2, pp. 118-132. https://doi.org/10.1108/09513550 810855627

[19] Radix A.P. Jati, I. (2014), "Local wisdom behind Tumpeng as an icon of Indonesian traditional cuisine", Nutrition \& Food Science, Vol. 44 Issue: 4, pp.324-334. DOI: 10.1108/ NFS-11-2013-0141

[20] Ranjabar, J. (2013), Sistem Sosial Budaya Indonesia, CV. Alfabeta, Bandung.

[21] Rokhmin, D. (2001), Potensi dan permasalahan pembangunan kawasan pesisir Indonesia, PK-Sumberdaya Pesisir dan Lautan, Institut Pertanian Bogor, Bogor.

[23] Soekanto, S. (2013), Sosiologi Suatu Pengantar, PT. Raja Grafindo Persada, Jakarta.

[24] Vrontis, D., Bresciani, S. and Giacosa, E. (2016), "Tradition and innovation in Italian wine family businesses", British Food Journal, Vol. 118 Issue: 8, pp.1883-1897. DOI: 10.1108/BFJ-05-2016-0192

[25] Wilkus, E.L., Francesconi, G.N. and Jäger, M. (2017), "Rural seed sector development through participatory varietal selection: Synergies and trade-offs in seed provision services and market participation among household bean producers in Western Uganda", Journal of Agribusiness in Developing and Emerging Economies, Vol. $7 \quad$ Issue: $\quad 2, \quad$ pp.174-196. https://doi.org/10.1108/JADEE-01-2016-0002

[26] Wirawan, B. and Dermawan, A. (2006), Panduan Pengembangan Marine Manajemen Area di Wilayah Coremap Indonesia Bagian Barat, Coremap II, Jakarta.

[27] Wulandari, S., Suwondo, S., \& Haryanto, R. (2018). Local Wisdom of Lubuk Larangan in Subayang River as a Source of Learning Environmental Education. In Proceedings of the UR International Conference on Educational Sciences (pp. 303-310).

[28] Yuliati, C. and Priyatna, N.P. (2014), "Lubuk Larangan: Dinamika Pengetahuan Lokal Masyarakat Dalam Pengelolaan Sumber Daya Perikanan Perairan Sungai Di Kabupaten Lima Puluh Kota", Jurnal Sosek KP, Vol. 9 No. 1, Available at: http://ejournal- balitbang.kkp.go.id/index.p hp. 